\title{
An optimised sequential extraction scheme for evaluation of vanadium mobility in soils
}

Yu-Hui Xu ${ }^{1}$, Jen-How Huang ${ }^{2, *}$, Helmut Brandl ${ }^{1}$

1. Institute of Evolutionary Biology and Environmental Studies, University of Zurich, CH8057 Zurich, Switzerland. E-mail: yuhui.xu@ieu.uzh.ch

2. Environmental Geosciences, University of Basel, CH-4056 Basel, Switzerland

Received 05 November 2015

Revised 15 December 2015

Accepted 06 February 2016

\begin{abstract}
Reviewing the current state of knowledge about sequential extraction applied for soil vanadium (V) fractionation, we identified an urgent requirement of an SE specified for V. Namely, almost all previous SE extracted only $8.4 \%-48 \%$ of total V in soils (excluding residue). Thus, we proposed an eight-step SE for $\mathrm{V}$ fractionation in soils according to the knowledge gained from literature and our own dissolution experiments with model minerals. After extracting the mobilisable and adsorbed $\mathrm{V}$ with de-ionised water and $5 \mathrm{mmol} / \mathrm{L}$ phosphate, $1 \mathrm{~mol} / \mathrm{L}$ pyrophosphate was applied to gather organic matter bound $\mathrm{V}$ which minimised the artefact dissolving $\mathrm{Al}$ and $\mathrm{Fe}$ (hydr)oxides occurred when using $\mathrm{HNO}_{3}-\mathrm{H}_{2} \mathrm{O}_{2}$ for extraction. Extraction with $0.4 \mathrm{~mol} / \mathrm{L} \mathrm{NH} \mathrm{N}_{2} \mathrm{OH} \cdot \mathrm{HCl}$ was highly selective toward manganese oxides. Fractionation of different crystalline $\mathrm{Al}$ and $\mathrm{Fe}$ (hydr)oxides associated V with 1 $\mathrm{mol} / \mathrm{L} \mathrm{HCl}, 0.2 \mathrm{~mol} / \mathrm{L}$ oxalate buffer and $4 \mathrm{~mol} / \mathrm{L} \mathrm{HCl}$ at $95^{\circ} \mathrm{C}$ especially improved the extractability of $\mathrm{V}$ incorporated with crystalline phase associated V. The suitability of our new SE scheme was confirmed by its higher selectivity against the target phases and higher extraction efficiencies (55\%-77\% of total V) with model minerals and 6 soils of different properties than previous SE.
\end{abstract}

Keywords: Vanadium; Sequential extraction; Soil; Mobility; Iron and aluminium (hydr)oxides

*Corresponding author. E-mail: jen-how.huang@unibas.ch 


\section{Introduction}

Vanadium (V) is a bright white ductile metal belonging to group $\mathrm{V}$ in the element periodic table (WHO, 2000). The global average concentration of V is $150 \mathrm{mg} / \mathrm{kg}$ in the earth's crust (Byerrum et al., 1974). Its concentration in soils varies depending on the geogenic enrichment and anthropogenic activities (e.g., mining and industrial activities) (Reimann and Caritat, 1998; Teng et al., 2011a). In trace amounts, V is an essential element for normal cell growth (Pyrzyńska and Wierzbicki, 2004). However, V might represent also a hazardous pollutant of the same class of mercury, lead and arsenic (Lazaridis et al., 2003). As such, V has been listed on the United States Environment Protection Agency candidate contaminant list 2 (CCL2). Furthermore, there are an increasing number of people affected by $\mathrm{V}$ pollution, especially in USA, China, Russia, and South Africa (Gummow, 2005; Teng et al., 2006; Yang et al., 2014).

The environmental risks of metal(loid)s in soils are primarily decided by their bioavailability and mobility, which depend on the binding state (Stalikas et al., 1999; Bacon and Davidson, 2008; Pueyo et al., 2008; Shaheen and Rinklebe, 2014). Analytical techniques such as X-ray absorption spectroscopy, X-ray diffraction, electron probe micro-analysis, energy-dispersive X-ray spectroscopy, laser-induced breakdown spectroscopy and laser ablation-ICP-MS may be applied to investigate the association of metal(loid)s with different soil solid phases (Keon et al., 2001; Gao, 2007; Rao et al., 2008; Thieme et al., 2010; Jantzi and Almirall, 2014; Cerqueira et al., 2015). They all showed limitations such as difficulties with data analysis of natural samples with high heterogeneity, problems with the separation of the mineral phases from the organic matters in organic soils and limited accessibility (Keon et al., 2001; Bacon and Davidson, 2008). Especially for X-ray absorption spectroscopy, the natural abundance of $\mathrm{Ti}$ in soils largely interfering the extended $\mathrm{X}$-ray absorption fine structure detection of V since Ti K-edge (4966 eV) is very close to V K-L3 (4953 eV). Some techniques are less suitable for quantify defined pools of metal(loid)s associated with defined solid phases in soils and sediments, e.g., X-ray diffraction energy-dispersive X-ray spectroscopy. In comparison, sequential extraction (SE) methods can not only reveal the association of metal(loid)s with soil solid phases but also quantify the pool at $\mathrm{mg} / \mathrm{kg}$ level. Despite the offset of artefacts during extraction (Rauret et al., 1999; Bacon and Davidson, 2008; Hass and Fine, 2010; Okoro et al., 2012; Drahota et al., 2014), SE may deliver useful information concerning the potentials of metal(loid)s releases from soils and sediments according to the dissolution behaviour of target phases (Keon et al., 2001; Rinklebe and Shaheen, 2014). Especially, SE was evidenced being more powerful to quantify the labile 
fractions than XAS (Scheinost et al., 2002). Sequential extraction is still very popular today due to its low costs and high accessibility as compared to the other analytical methods for solid phases. In 2014 and 2015, there are still a number of new SE schemes for trace elements were proposed (Al-Hwaiti et al., 2014; Drahota et al., 2014; Rinklebe and Shaheen, 2014; Shaheen and Rinklebe, 2014; Unsal et al., 2014; He et al., 2015).

To date, Community Bureau of Reference (BCR) is the most popular SE schemes (Ure et al., 1993; Tessier et al., 1979). Some other SE schemes are also available with various combinations of extraction steps and sequences (Wang et al., 1999; Wenzel et al., 2001; Rao et al., 2008; Chang et al., 2009; Huang and Kretzschmar, 2010; Teng et al., 2011a; Aydin et al., 2012; Shaheen and Rinklebe, 2014). Since the first SE scheme was developed in late 1970s, there are already numerous SE schemes being proposed (Bacon and Davidson, 2008; Rao et al., 2008; Hass and Fine, 2010; Zimmerman and Weindorf, 2010; Okoro et al., 2012; Shaheen and Rinklebe, 2014), which first focusing on cadmium, chromium, copper, iron, lead, manganese, nickel and zinc, and thereafter on arsenic, mercury, selenium and radionuclides (Bacon and Davidson, 2008; Pueyo et al., 2008; Hass and Fine, 2010; Okoro et al., 2012). However, none of them was designed for the fractionation of $\mathrm{V}$ in soils. Khan et al. (2013) presented the only one study with major focus on SE of V in soils. Nevertheless, they aimed at shortening the extraction time of BCR scheme instead improving the extraction recovery. With the representative SE schemes, the previous studies reported surprisingly $70 \%-90 \%$ of total soil $\mathrm{V}$ in the residual phases (Table 1). Vanadium geochemistry is very different from the other metal(loid)s. Unlike most other metal(loid)s exiting mostly as either cation or anion in soils, $\mathrm{V}$ may present as both cation $\left(\mathrm{H}_{2} \mathrm{VO}_{4}{ }^{-}, \mathrm{HVO}_{4}{ }^{2-}\right)$ and anion $\left(\mathrm{VO}_{2}{ }^{+}\right.$, $\mathrm{VO}^{2+}$ ) (Yang et al., 2010). As a result, a specific SE scheme is needed for soil V to estimate its association with different solid phases in soils.

The industrial demand of $\mathrm{V}$ increased drastically currently with tripled global $\mathrm{V}$ demand in 2016 than 2002 being predicted (Perles, 2012). The mining and refinery activities may distribute $\mathrm{V}$ in the soil environment (Yang et al., 2014). These altogether suggest increased risks of $\mathrm{V}$ pollution in soils, which may subsequently affect the human health. Thus, a SE scheme specified for evaluation of $\mathrm{V}$ mobility becomes indispensable. Overall, the objectives of this study were (1) to review the current state of knowledge about SE schemes used for V fractionation in soils and to highlight the urgent requirement of a SE scheme for V and (2) to propose a specific SE scheme for $\mathrm{V}$ based on the existing literature and on our own preliminary extraction experiments. 


\section{Materials and methods}

\subsection{Soil sampling}

A permanently anoxic wetland soil (mineral subsoil, 50-60 cm) and a well-drained forest soil (subsoil, 12-30 cm) were sampled in northeast Bavaria, Germany (Huang and Matzner, 2007). A paddy soil (surface soil, 30-35 cm) was sampled in Munshiganj district, $30 \mathrm{~km}$ south of Dhaka, Bangladesh (Huang and Kretzschmar, 2010). A mining (topsoil, 0-20 cm) and two smelter soils (topsoil, 0-20 cm and subsoil, 20-40 cm) were collected in Panzhihua, SW-China, where is famous worldwide for mining and smelting V-Ti magnetite (Teng et al., 2011a). All soil samples were homogeneously mixed with at least three random samples from each sample site. After being either freeze- or air-dried and sieved to $2 \mathrm{~mm}$, soil samples were stored at $4^{\circ} \mathrm{C}$ before use. The characteristics of the aforementioned soils are shown in Table 2 .

\subsection{Reagents and instruments}

All reagents used in this study were of analytical grade and diluted to the required concentration with de-ionised water. All glassware was previously soaked in $14 \% \mathrm{HNO}_{3}$ $(V / V)$ and rinsed with de-ionised water before use. The analysis of $\mathrm{V}$ and $\mathrm{Fe}$ in extractants were performed with ICP-MS (Agilent 7500ce, Japan) by monitoring ${ }^{51} \mathrm{~V}$ and using $\mathrm{He}$ collision cell to eliminate the $\mathrm{ClO}^{+}$interference (D'Ilio et al., 2011; Rousis et al., 2014) and ICP-OES (Vista-Pro radial, Varian, Germany). Total V in soils were quantified with X-ray fluorescence spectrometry (XRF, Spectro-X-Lab 2000, Germany).

\subsection{Sequential extraction procedures}

Table 3 summarises our newly proposed eight-step SE scheme (SE I) and a second SE scheme (SE II) modified from the schemes of BCR (Davidson et al., 1998), Tessier et al. (1979) and Wenzel et al. (2001), including the information of target phases and extraction conditions. All SE was conducted with $1.0 \mathrm{~g}$ dry soil in a $50-\mathrm{mL}$ centrifugation tube by shaking horizontally at $200 \mathrm{r} / \mathrm{min}$. After each extraction step, the tube was centrifuged for 15 min at $5000 \times g$ and decanted. The remaining solids were twice washed with $8 \mathrm{~mL}$ de-ionised water and the residue was taken for the subsequent extraction step. The final residue was additionally digested with $\mathrm{HNO}_{3}-\mathrm{H}_{2} \mathrm{O}_{2}-\mathrm{HF}(5: 3: 2, V / V / V)$ with the assistance of microwave. The supernatant of each extraction step was filtered to $0.45 \mu \mathrm{m}$ with cellulose acetate and nylon filter papers and stored in polyethylene bottles at $4^{\circ} \mathrm{C}$ before analysis with ICP-MS. 
We evaluated the selectivity of each extraction step by comparing the solubility of synthesised minerals such as ferrous sulphide (FeS; Fluka, Buchs, Switzerland), manganese oxide $\left(\mathrm{MnO}_{2}\right.$, pyrolusite) and aluminum hydroxide $\left(\mathrm{Al}(\mathrm{OH})_{3}\right.$; both Merck, Darmstadt, Germany), boehmite ( $\gamma-\mathrm{AlOOH}$; Sasol, Houston, USA), freshly-prepared 2-line ferrihydrite and goethite $(\alpha-\mathrm{FeOOH})$ at 4 and $8 \mathrm{~g} / \mathrm{L}$ during each extraction step. Based on X-ray diffraction analysis, ferrihydrite and $\gamma$ - $\mathrm{AlOOH}$ were poorly crystalline and $\mathrm{FeS}, \mathrm{MnO}_{2}$, $\mathrm{Al}(\mathrm{OH})_{3}$, and $\alpha-\mathrm{FeOOH}$ were well-crystalline phases. Furthermore, we validated the proposed scheme by examining whether the results obtained from the SE matched with the characteristics of the forest, wetland, mining, smelter and paddy soils (Table 2). To check the correctness of $\mathrm{V}$ mass balance, the sum of $\mathrm{V}$ concentrations from each extraction step including the residue was compared with the total $\mathrm{V}$ concentrations in soils measured with XRF. The method precision of each extraction step was evaluated by the coefficient of variation of each fraction with SPSS 20.

\section{Results and discussion}

\subsection{Sequential extraction for vanadium in mineral soils in literature}

Table 1 summarised all SE schemes used to fractionate $\mathrm{V}$ in soils to date. The most commonly used scheme was exchangeable (sorbed)/carbonate/reducible (or $\mathrm{Fe}$ and $\mathrm{Mn}$ (hydr)oxides)/oxidisable (or organic matter and sulphides) fractions. Wenzel et al. (2002) and Hall et al. (1996) additionally separated Fe and Al (hydr)oxide phases into two fractions based on the crystallinity. Generally, the extractant used for mobilisable fractions was water, neutral salt or weak acid which is well-accepted. Almost all studies showed that less than $1 \%$ of total $\mathrm{V}$ in soils was exchangeable (Table 1), suggesting the general low mobility of $\mathrm{V}$ in soils (Hall et al., 1996). In most cases, hydroxylamine hydrochloride $\left(\mathrm{NH}_{2} \mathrm{OH} \cdot \mathrm{HCl}\right)$ was applied to extract reducible phases/Fe and $\mathrm{Mn}$ (hydr)oxides and extracted less than $12 \%$ of total $\mathrm{V}$ in soils (Table 1). The oxidisible $\mathrm{V}$ was usually extracted by $\mathrm{H}_{2} \mathrm{O}_{2}$ and a proportion of $<16 \%$ of total $\mathrm{V}$ has been found among the different soils. Since oxidation may also release organic matter bound $\mathrm{V}$, oxidation reagents such as $\mathrm{KClO}_{3}-\mathrm{HCl}$ and $\mathrm{HNO}_{3}$ were proposed also to digest the organic matter associated phases (Hall et al., 1996). The predominance of $\mathrm{V}$ in reducible phases/Fe and $\mathrm{Mn}$ (hydr)oxides (45\%-64\%) were only found in those soils with external V origin e.g. via experimentally spiking (Castillo-Carrión et al., 2007) or irrigation of waste water (Fitamo et al., 2007). This mirrored that added V, mostly V(V), was predominately associated with $\mathrm{Fe} / \mathrm{Mn}$ (hydr)oxides due to its strong adsorption affinity 
(Peacock and Sherman, 2004). Most SE schemes in literature allowed extract 10\%-30\% of total $\mathrm{V}$ in natural soils, when excluding the residue. Such low extraction efficiencies may reflect the incorporation of $\mathrm{V}$ into the lattice crystalline minerals as tetravalent (V(IV)) and trivalent V (V(III)) cations (e.g. $\mathrm{VO}^{2+}$ and $\mathrm{V}^{3+}$ ) (Gehring et al., 1993; Klein et al., 1993; Schwertmann and Pfab, 1994). These altogether suggest the current SE methods in literature being still unsuitable for fractionation of $\mathrm{V}$ in soils, especially when $\mathrm{V}$ is associated with recalcitrant phases.

\subsection{Development of new sequential extraction schemes for vanadium in soils}

For safety reason, we avoided using very strong oxidants, acids and toxic reagents to propose our novel SE scheme (SE I). First, we extracted the soil with de-ionised water to quantify the pool of readily mobilisable $\mathrm{V}$. Namely, the water soluble phase constitutes the most mobile and potentially the most available metal(loid)s. Then, because the mobile V in soils is mostly pentavalent (V(V)) (Baken et al., 2012), phosphate solution was used for exchange strongly adsorbed $\mathrm{V}$ via competitive adsorption due to the similarity of the chemical structure between phosphate and vanadate (Prathap and Namasivayam, 2010). Phosphate may outperform vanadate because of its smaller size and higher charge density (Lookman et al., 1995; Rietra et al., 1999; Wenzel et al., 2001). We decreased phosphate concentrations to $5 \mathrm{mmol} / \mathrm{L}$ and shortened the extraction time to $8 \mathrm{hr}$, which successfully extracted more than $80 \%$ of exchangeable arsenic in soils (Huang and Kretzschmar, 2010), as compared Wenzel et al. (2001). The use of lower phosphate concentration and shortage of the extraction duration may minimise to extract organic matter associated V. Namely, phosphate is capable of complexation with polyvalent cations, e.g., $\mathrm{Ca}^{2+}, \mathrm{Al}^{3+}$ and $\mathrm{Fe}^{3+}$, which are responsible for maintaining organic matter in a flocculated and insoluble state in soils, however weaker than pyrophosphate (Lente et al., 2000). Both acetic acid (HOAc) and EDTA were also common reagents for quantifying mobilisable and bioavailable metal(loid)s (Teng et al., 2011b; Tian et al., 2014). However, HOAc was insufficient to release the adsorbed vanadate since it only slightly lowered the $\mathrm{pH}$ and almost did not change the adsorption affinity of vanadate to soil particles (Tian et al., 2014). Wenzel et al. (2001) found that EDTA was not selective enough because it may dissolve considerable amounts of $\mathrm{Fe}$ and $\mathrm{Al}$ (hydr)oxides. Following phosphate extraction, we used pyrophosphate to destabilise the soil organic matter in complex with polyvalent cations and released V associated. Pyrophosphate is commonly used to extract metal(loid)s bound to organic matters and to avoid the dissolution of metal oxides 
(Huang and Kretzschmar, 2010). Since pyrophosphate may also exchange adsorbed vanadate from soils, phosphate extraction was done prior to pyrophosphate extraction. The dissolution test with different model minerals showed that none of the model minerals could be dissolved by $5 \mathrm{mmol} / \mathrm{L}$ phosphate and about $1 \%$ of boehmite and $\mathrm{FeS}$ was dissolved during pyrophosphate extraction (Table 4), highlighting also the much stronger ability of pyrophosphate to complex metals than phosphate. The design of our extraction sequence allowed us conclude that the amount of organic matter associated $\mathrm{V}$ extracted by $5 \mathrm{mmol} / \mathrm{L}$ phosphate was trivial as compared to $0.1 \mathrm{~mol} / \mathrm{L}$ pyrophosphate. Still, future research is essential to quantify how good the two phosphate extractions differentiate adsorbed and organic matter associated V.

To extract $\mathrm{V}$ associated with $\mathrm{Fe}$ and $\mathrm{Al}$ (hydr)oxides in soils, most methods in literature used $\mathrm{NH}_{2} \mathrm{OH} \cdot \mathrm{HCl}$ alone or in combination with $\mathrm{HCl}$ or $\mathrm{HOAc}$ at high temperatures (Table 1). However, $\mathrm{NH}_{2} \mathrm{OH} \cdot \mathrm{HCl}$ has been found inefficient to dissolve amorphous ferrihydrite in the given time, whereas our preliminary experiments indicated complete dissolution of Mn oxides in $30 \mathrm{~min}$ with $0.4 \mathrm{~mol} / \mathrm{L} \mathrm{NH} \mathrm{NH}_{2} \mathrm{OH} \cdot \mathrm{HCl}$ (Table 4). Dissolution of boehmite and $\mathrm{FeS}$ were $<1.5 \%$ and $<0.15 \%$ for ferrihydrite and goethite, showing the high dissolution selectivity of $0.4 \mathrm{~mol} / \mathrm{L} \mathrm{NH} \mathrm{NH}_{2} \mathrm{OH} \cdot \mathrm{HCl}$ towards $\mathrm{MnO}_{2}$. Hence we utilised $\mathrm{NH}_{2} \mathrm{OH} \cdot \mathrm{HCl}$ to quantify $\mathrm{Mn}$ oxide instead of Fe and Al (hydr)oxide bound V. Given that V(III) and V(IV) may incorporate into the lattice of soil minerals of different crystallinity, we refined the fraction associated with $\mathrm{Fe}$ and Al (hydr)oxides by separating it into very poorly crystalline, poorly crystalline and crystalline. The corresponding extraction reagents were $1 \mathrm{~mol} / \mathrm{L} \mathrm{HCl}, 0.25 \mathrm{~mol} / \mathrm{L}$ oxalate buffer and $4 \mathrm{~mol} / \mathrm{L}$ hot $\mathrm{HCl}$, respectively. The extraction sequence using $1 \mathrm{~mol} / \mathrm{L} \mathrm{HCl}$ and $0.25 \mathrm{~mol} / \mathrm{L}$ oxalate buffer was adapted from Keon et al. (2001) and higher $\mathrm{HCl}$ concentrations or hot $\mathrm{HCl}$ should be avoided to minimise ligand-promoted dissolution of crystalline $\mathrm{Fe}$ (hydr)oxides (Huang and Kretzschmar, 2010). Our dissolution test showed complete dissolution of poorly crystalline ferrihydrite and $6.3 \%$ of poorly crystalline boehmite using 1 $\mathrm{mol} / \mathrm{L} \mathrm{HCl}$ (Table 4). The percentage of crystalline goethite and $\mathrm{Al}(\mathrm{OH})_{3}$ dissolved were comparably low (3.9\% and $1.2 \%$, respectively). Thus, the extraction based on $1 \mathrm{~mol} / \mathrm{L} \mathrm{HCl}$ was especially selective towards poorly crystalline Fe (hydr)oxides. The dissolution ability of oxalate buffer was generally similar to $1 \mathrm{~mol} / \mathrm{L} \mathrm{HCl}$ but may dissolve more pooly crystalline boethmite (10.9\%) than $1 \mathrm{~mol} / \mathrm{L} \mathrm{HCl}$ (Table 4). Dissolution of the crystalline phases is the most challenging for SE. Using aqua regia and strong oxidant acids, which were frequently taken for dissolution of the residual phase (Table 1), may risk to dissolve partially silicate 
(Yuan et al., 2004; Silveira et al., 2006; Rao et al., 2011). Cornell and Schwertmann (2003) suggest to dissolve crystalline $\mathrm{Fe}$ (hydr)oxide with $6 \mathrm{~mol} / \mathrm{L} \mathrm{HCl}$ at room temperature. However, our preliminary study showed slight dissolution of goethite and the dissolution of boehmite was less effective (Table 4). Increasing temperature to $95^{\circ} \mathrm{C}$, complete dissolution of goethite and boehmite was achieved with $4 \mathrm{~mol} / \mathrm{L} \mathrm{HCl}$ in one hour and therefore was used in our SE scheme to extract crystalline Fe and $\mathrm{Al}$ (hydr)oxide associated V. Reduced minerals such as sulphides may present in anoxic and redox fluctuated soils such as wetland, flooded and paddy soils. Our extraction steps used for $\mathrm{Fe}$ and $\mathrm{Al}$ (hydr)oxides may also extract amorphous sulphides, i.e., $1 \mathrm{~mol} / \mathrm{L} \mathrm{HCl}$ may extract acid volatile sulphide and $4 \mathrm{~mol} / \mathrm{L}$ hot $\mathrm{HCl}$ was evidenced to dissolved $64.1 \%$ of well-crystalline $\mathrm{FeS}$.

We proposed a second SE scheme (SE II) for $\mathrm{V}$ fractionation in mineral soils by combining steps from the most frequently used schemes of Tessier et al. (1979), BCR (Davidson et al., 1998) and Wenzel et al. (2001). Sequential extraction II served as a comparison of the effectiveness and feasibility for our newly proposed eight-step SE scheme (SE I) (Table 3). We added de-ionised water extraction as first step to quantify the readily mobilisable V. Acetic acid was chosen to extract exchangeable $\mathrm{V}$ by lowering $\mathrm{pH}$ and additionally to extract carbonate phases (Tessier et al., 1979; Davidson et al., 1998). Iron and Al (hydr)oxides fraction was categorised into amorphous and crystalline phases based on Wenzel et al. (Wenzel et al., 2001) using oxalate buffer in combination with ascorbic acid. Subsequently, $\mathrm{HNO}_{3}-\mathrm{H}_{2} \mathrm{O}_{2}$ based extraction was applied to decompose organic matters (Tessier et al., 1979).

\subsection{Comparison of the selected schemes of sequential extraction}

To verify the suitability of the eight-step SE scheme (SE I), we first compared its results on two soil samples of very different characteristics with those obtained with SE II scheme (Fig. 1). The mining soil is slightly basic ( $\mathrm{pH} \mathrm{7.6)} \mathrm{and} \mathrm{enriched} \mathrm{with} \mathrm{geogenic} \mathrm{V} \mathrm{(Yang} \mathrm{et} \mathrm{al.,}$ 2014). The forest soil is acidic ( $\mathrm{pH} 3.5)$ and developed from granite enriched with $\mathrm{Fe}$ and $\mathrm{Al}$ oxides and organic matter due to podsolisation (Huang et al., 2004). The comparison demonstrated that $5 \mathrm{mmol} / \mathrm{L}$ phosphate released strongly adsorbed $\mathrm{V}$ more efficiently (e.g., $3.9 \%$ in the forest soil) than $1 \mathrm{~mol} / \mathrm{L}$ HOAc solution (e.g., $2.2 \%$ in the forest soil). Namely, the $\mathrm{pH}$ in the HOAc extracts of both soils was measured as 4, which was insufficient to weaken the adsorption affinity of vanadate (Peacock and Sherman, 2004). The proportion of $\mathrm{V}$ bound to organic matter in the forest soil was higher based on pyrophosphate extraction 
(9.8\%) than that based on $\mathrm{HNO}_{3}-\mathrm{H}_{2} \mathrm{O}_{2}$ extraction (8.7\%). Pyrophosphate dissolves organic matter from soils by forming metal complexes, whereas $\mathrm{HNO}_{3}-\mathrm{H}_{2} \mathrm{O}_{2}$ extracts organic matter bound metal(loid)s by oxidising organic matter to $\mathrm{CO}_{2}$. The forest soil was collected from a Bhs horizon of a podzol soil profile enriched with organic substances (8.27\% organic carbon) precipitated from the forest floor. Thus, a high percentage of organic matter bound $\mathrm{V}$ can be expected. The mining soil contained less organic carbon $(2.15 \%)$. Still, a similarly higher percentage of organic bound $\mathrm{V}(5.9 \%)$ in the mining soil to that in the forest soil was found based on $\mathrm{HNO}_{3}-\mathrm{H}_{2} \mathrm{O}_{2}$ extraction. In comparison, pyrophosphate measured only $0.3 \%$ of total $\mathrm{V}$ associated with organic matter in the mining soil. Apparently, $\mathrm{H}_{2} \mathrm{O}_{2}-\mathrm{HNO}_{3}$ released additional $\mathrm{V}$ via the dissolution of considerable amounts of $\mathrm{Fe}$ and $\mathrm{Al}$ (hydr)oxides, as indicated by higher concentrations of $\mathrm{Fe}$ in the $\mathrm{H}_{2} \mathrm{O}_{2}-\mathrm{HNO}_{3}$ extracts $(>56,000 \mathrm{mg} / \mathrm{kg})$ than those in the pyrophosphate extracts $(625 \mathrm{mg} / \mathrm{kg}$ Fe for mining soil, $2107 \mathrm{mg} / \mathrm{kg} \mathrm{Fe}$ for forest soil). These results indicated that pyrophosphate may be not only more effective but also more selective against the organic matter bound $\mathrm{V}$ than $\mathrm{HNO}_{3}-\mathrm{H}_{2} \mathrm{O}_{2}$.

The presence of significant amounts of $\mathrm{V}$ associated with Mn oxides $(9.3 \%)$ in the forest soil demonstrated the usefulness of $\mathrm{NH}_{2} \mathrm{OH} \cdot \mathrm{HCl}$ extraction step in SE I (Fig. 1). Overall, SE I quantified more $\mathrm{V}$ associated with metal (hydr)oxides in the forest soil (total of 63\%) than SE II did (total of $48 \%$ ). Sequential extraction I measured $16 \%$ of total V associated with very poorly and poorly crystalline $\mathrm{Fe}-\mathrm{Al}$ (hydr)oxides and $37 \%$ with crystalline $\mathrm{Fe}-\mathrm{Al}$ (hydr)oxides in the forest soil. Based on SE II, there were only $20 \%$ of total V bound to amorphous (hydr)oxides and $28 \%$ bound to crystalline (hydr)oxides. Such difference was much more apparent in the mining soil. There was $14 \%$ of total $\mathrm{V}$ bound to Mn oxides and poorly crystalline $\mathrm{Fe}-\mathrm{Al}$ (hydr)oxides, and $43 \%$ bound to crystalline $\mathrm{Fe}-\mathrm{Al}$ (hydr)oxides according to SE I. In comparison, only $1.0 \%$ of total $\mathrm{V}$ was found in the amorphous oxides fraction and $1.0 \%$ in crystalline oxides fraction by SE II. Although the Fe concentration in the mining soil (11.1\%) was much higher than in the forest soil (1.69\%), SE II measured much less V associated with Fe-Al (hydr)oxides in the mining soil $(2.1 \%)$ than in the forest soil (48\%). This is in disagreement with the positive correlation between Fe and V generally found in soils (Aide, 2005). Of course, such discrepancy can be explained by the abundance of geogenic $\mathrm{V}$ associated with more recalcitrant phase, e.g., crystalline V-Ti magnetite in the mining soil. However, SE I largely improved the extraction efficiency of metal oxides bound $\mathrm{V}$ in the mining soil so that the ratio of the proportion of metal oxides bound $\mathrm{V}$ between both soils was almost 1:1. Thus, SE I was able to refine and target the fractions related to the metal 
(hydr)oxides with greater efficiency than SE II. Overall, SE I quantified $77 \%$ and $58 \%$ of total $\mathrm{V}$ excepted the residual fraction in the forest soil and mining soil, respectively (Fig. 1). Sequential extraction II, which is a combination of the most commonly used SE schemes, extracted in comparison only $61 \%$ and $8 \%$ of total $\mathrm{V}$ in the forest and mining soils, respectively, suggesting that our newly proposed eight-step SE scheme (SE I) largely improved the ability of SE to fractionate V in soils.

\subsection{Verification of the proposed eight-step sequential extraction scheme with real soil samples}

Four further soils of different characteristics at 23.5 to $784 \mathrm{mg} / \mathrm{kg} \mathrm{V}$ (Table 2) were analysed to check the adaptability and reproducibility of our eight-step SE scheme (SE I) in addition to the selectivity test with model minerals during the development (Section 3.2). When including the results of the mining soil and forest soil, our newly proposed SE scheme is highly superior to the previous schemes by increasing the total extraction recovery from averagely $27 \%$ of total V (8.4\%-48\%) in 192 soils in literature to 65\% (55\%-77\%) in 6 soil samples investigated here when residues not included. Satisfactory V mass balance was shown with averagely $95 \%$ of $\mathrm{V}$ in soils was quantified with our new SE scheme (including residue) as compared to XRF values. The variation coefficients of each extraction step averaged $3.8 \%$, indicating our extraction method was highly precise (Tables S1 and S2). The low precision was mainly from the water soluble fraction (13\%) and residual fraction (19\%) due to the very low concentrations in the water extracts and trace amounts of soils left for digestion, respectively.

The proportion of water-soluble fraction of the six soils samples was $0.6 \%(0.1 \%-1.1 \%)$ and the exchangeable fraction was $1.2 \%(0.1 \%-3.9 \%)$. The $5 \mathrm{mmol} / \mathrm{L}$ phosphate was plausible to effectively release strongly adsorbed V from soils via competitive adsorption, which is indicated by the much lower concentrations of $\mathrm{V}$ in the phosphate extracts of the different soils investigated $(0.15-7.7 \mu \mathrm{mol} / \mathrm{L})$. Excessive competitive species are known being able to release adsorbed species effectively (Sparks, 2003). In this study, the phosphate concentration used was approximately 3 levels of magnitude higher than adsorbed vanadate in the extracts. The large excess of phosphate warranty also the recovery of adsorbed little influenced by the original soil $\mathrm{pH}$. Independently of the soil characteristics, most $\mathrm{V}$ in soils was scarcely mobilisable (Figs. 1 and 2). The very small pool of readily mobilisable $\mathrm{V}$ found in these soils is in agreement with the results derived from the soil column leaching experiments (Yang et al., 2014). The fraction associated with organic matters ranged from 
$0.3 \%$ to $24 \%$ and was well related with the soil organic carbon contents at the significant level 0.02 (excluding the smelter topsoil which was artificially affected). The highest proportions of $\mathrm{V}$ associated with organic matter were found in the forest and wetland soils which contain $8.3 \%$ and $5.6 \%$ organic matter, respectively (Table 2). The proportion of $\mathrm{V}$ associated with Mn oxides averaged only $2.6 \%(0.2 \%-9.3 \%)$, coinciding well with the general low content of Mn oxides in soils compared to Fe and Al (hydr)oxides (Sparks, 2003). In the wetland soil, the proportion of the reducible fraction (i.e., Mn and Fe (hydr)oxides) was much smaller than in the other soils, which is plausible due to its anoxic nature. On average, $34 \%$ (28\%-43\%) of total $\mathrm{V}$ was bound to crystalline $\mathrm{Fe}$ and $\mathrm{Al}$ (hydr)oxides and 9.2\% (4.6\%-17\%) $\mathrm{V}$ was associated with poorly crystalline Fe and Al (hydr)oxides. The proportion of very poorly crystalline fraction was $8.6 \%(1.7 \%-22 \%)$. Vanadium was more strongly associated with the crystalline $\mathrm{Fe}$ and $\mathrm{Al}$ (hydr)oxides than the amorphous $\mathrm{Fe}$ and $\mathrm{Al}$ (hydr)oxides, which reflects the incorporation of geogenic V in the lattice of soil minerals as V(III) and V(IV) (Gehring et al., 1993; Klein et al., 1993; Schwertmann and Pfab, 1994). In addition, the proportion of V associated with $\mathrm{Fe}$ and $\mathrm{Al}$ (hydr)oxides increased with the increasing concentrations of total $\mathrm{V}$ and Fe in soils, supporting the close correlation between V and Fe in soils (Kaur et al., 2009).

Since our scheme was developed using natural and low contaminated soils, it may not be able to resolve certain $\mathrm{V}$ containing wastes such as dicalcium silicate, brownmillerite, hydrogarnet and sodalite/cancrinite (De Windt et al., 2011; Frost et al., 2012). Accordingly, care should be taken for applying this scheme to the soils embodying high amounts of $\mathrm{V}$ containing wastes.

\section{Conclusions}

We have demonstrated that our newly-proposed eight-step SE was able to target the distinct and environmentally important forms of $\mathrm{V}$ in soils. The new SE scheme efficiently refined the fraction of $\mathrm{V}$ bound to $\mathrm{Mn}, \mathrm{Fe}$ and $\mathrm{Al}$ (hydr)oxides, which can be useful for the evaluation of $\mathrm{V}$ mobilisation under reducing conditions. The largely improved extractability against crystalline $\mathrm{Fe}$ and $\mathrm{Al}$ (hydr)oxide enabled for the first time to identify the presence of noticeable amounts of geogenic $\mathrm{V}$ incorporated in the lattice of soil minerals. Furthermore, the newly-proposed SE scheme is highly superior to the previous schemes by largely increasing the total extraction efficiency. It extracted averagely 65\% (55\%-77\%) of total $\mathrm{V}$ in 6 natural soil samples investigated (residues not included), while the schemes used in literature extracted $27 \%$ of total V (8.4\%-48\%) of total V in 192 natural soil samples. 


\section{Acknowledgments}

We like to thank Gunter Ilgen (University of Bayreuth, Germany) for the support with analysis. We also thank Dr. Sarah Pellkofer and Dr. Matteo Brezzi for the help with language. This work was supported by the China Scholarship Council (No. 2011624130) and the Swiss National Science Foundation (No. PZ00P2 142232). 


\section{References}

Abollino, O., Giacomino, A., Malandrino, M., Mentasti, E., Aceto, M., Barberis, R., 2006. Assessment of metal availability in a contaminated soil by sequential extraction. Water, Air, Soil Pollut. 173 (1-4), 315-338.

Agnieszka, J., Barbara, G., 2012. Chromium, nickel and vanadium mobility in soils derived from fluvioglacial sands. J. Hazard. Mater. 237, 315-322.

Aide, M., 2005. Geochemical assessment of iron and vanadium relationships in oxic soil environments. Soil Sediment Contam. 14 (5), 403-416.

Al-Hwaiti, M., Tardio, J., Reynolds, H., Bhargava, S., 2014. Selectivty assessments of a sequential extraction procedure for potential trace metals' mobility and bioavailability in phosphate rocks from Jordan phosphate mines. Soil Sediment Contam. 23 (4), 417-436.

Aydin, F., Saydut, A., Gunduz, B., Aydin, I., Hamamci, C., 2012. Chemical speciation of vanadium in coal bottom ash. CLEAN-Soil, Air, Water 40 (4), 444-448.

Bacon, J.R., Davidson, C.M., 2008. Is there a future for sequential chemical extraction? Analyst 133 (1), 25-46.

Baken, S., Larsson, M.A., Gustafsson, J.P., Cubadda, F., Smolders, E., 2012. Ageing of vanadium in soils and consequences for bioavailability. Eur. J. Soil Sci. 63 (6), 839-847.

Byerrum, R.U., Eckardt, R.E., Hopkins, L.L., Libsch, J.F., Rostoker, W., Zenz, C., 1974. Vanadium. Washington DC, USA, National Academy of Sciences.

Castillo-Carrión, M., Martín-Rubí, J.A., de Quirós, E.O.B., 2007. The distribution and fixation of trace elements by the Vertisols of Malaga, southern Spain. Sci. Total Environ. $378(1), 28-35$.

Cerqueira, B., Arenas-Lago, D., Andrade, M.L., Vega, F.A., 2015. Using time of flight secondary ion mass spectrometry and field emission scanning electron microscopy with energy dispersive X-ray spectroscopy to determine the role of soil components in competitive copper and cadmium migration and fixation in soils. Geoderma 251-252, 6577.

Chang, C.Y., Wang, C.F., Mui, D.T., Chiang, H.L., 2009. Application of methods (sequential extraction procedures and high-pressure digestion method) to fly ash particles to determine the element constituents: A case study for BCR 176. J. Hazard. Mater. 163 (2), 578-587.

Cornell, R.M., Schwertmann, U., 2003. The Iron Oxides: Structure, Properties, Reactions, Occurences and Uses, 2nd ed. Wiley-VCH, Weinheim, Germany. 
D’Ilio, S., Violante, N., Majorani, C., Petrucci, F., 2011. Dynamic reaction cell ICP-MS for determination of total As, $\mathrm{Cr}$, Se and V in complex matrices: Still a challenge? A review. Anal. Chim. Acta 698 (1), 6-13.

Davidson, C.M., Duncan, A.L., Littlejohn, D., Ure, A.M., Garden, L.M., 1998. A critical evaluation of the three-stage BCR sequential extraction procedure to assess the potential mobility and toxicity of heavy metals in industrially-contaminated land. Anal. Chim. Acta 363 (1), 45-55.

Drahota, P., Grösslová, Z., Kindlová, H., 2014. Selectivity assessment of an arsenic sequential extraction procedure for evaluating mobility in mine wastes. Anal. Chim. Acta 839, 34 43.

De Windt, L., Chaurand, P., Rose, J., 2011. Kinetics of steel slag leaching: batch tests and modeling. Waste Manage. 31(2), 225-235.

Fitamo, D., Itana, F., Olsson, M., 2007. Total contents and sequential extraction of heavy metals in soils irrigated with wastewater, Akaki, Ethiopia. Environ. Manage. 39 (2), 178193.

Frost, R.L., Xi, Y., 2012. Vibrational spectroscopic study of the minerals cavansite and pentagonite $\mathrm{Ca}\left(\mathrm{V}^{4+} \mathrm{O}\right) \mathrm{Si}_{4} \mathrm{O}_{10} \cdot 4 \mathrm{H}_{2} \mathrm{O}$. Spectrochim. Acta A. 95, 263-269.

Gao, X., 2007. Speciation and Geochemical Cycling of Lead, Arsenic, Chromium, and Cadmium in a Metal-Contaminated Histosol, PhD thesis. Purdue University, West Lafayette, Indiana.

Gehring, A.U., Fry, I.V., Luster, J., Sposito, G., 1993. The chemical form of vanadium (IV) in kaolinite. Clays Clay Miner. 41 (6), 662-167.

Güler, C., Alpaslan, M., Kurt, M.A., Temel, A., 2010. Deciphering factors controlling trace element distribution in the soils of Karaduvar industrial-agricultural area (Mersin, SE Turkey). Environ. Earth Sci. 60 (1), 203-218.

Gummow, B., 2005. Vanadium Mining and Cattle Health: Sentinel Studies, Epidemiological and Veterinary Public Health Issues, $\mathrm{PhD}$ thesis. Utrecht University, Utrecht, Netherlands.

Hall, G.E.M., Gauthier, G., Pelchat, J.-C., Pelchat, P., Vaive, J.E., 1996. Application of a sequential extraction scheme to ten geological certified reference materials for the determination of 20 elements. J. Anal. At. Spectrom. 11 (9), 787-796. 
Hass, A., Fine, P., 2010. Sequential selective extraction procedures for the study of heavy metals in soils, sediments, and waste materials - a critical review. Crit. Rev. Environ. Sci. Technol. 40 (5), 365-399.

He, J., Liu, G.L., Zhu, D.W., Cai, J.B., Zhou, W.B., Guo, W.W., 2015. Sequential extraction of calcium in lake sediments for investigating the cycle of phosphorus in water environment. Int. J. Environ. Sci. Technol. 12 (3), 1123-1136.

Huang, J.-H., Kretzschmar, R., 2010. Sequential extraction method for speciation of arsenate and arsenite in mineral soils. Anal. Chem. 82 (13), 5534-5540.

Huang, J.-H., Matzner, E., 2007. Biogeochemistry of organic and inorganic arsenic species in a forested catchment in Germany. Environ. Sci. Technol. 41 (5), 1564-1569.

Huang, J.-H., Schwesig, D., Matzner, E., 2004. Organotin compounds in precipitation, fog and soils of a forested ecosystem in Germany. Environ. Pollut. 130 (2), 177-186.

Jantzi, S.C., Almirall, J.R., 2014. Elemental analysis of soils using laser ablation inductively coupled plasma mass spectrometry (LA-ICP-MS) and laser-induced breakdown spectroscopy (LIBS) with multivariate discrimination: tape mounting as an alternative to pellets for small forensic transfer specimens. Appl. Spectrosc. 68 (9), 963-974.

Kaur, N., Singh, B., Kennedy, B.J., Gräfe, M., 2009. The preparation and characterization of vanadium-substituted goethite: The importance of temperature. Geochim. Cosmochim. Acta 73 (3), 582-593.

Keon, N.E., Swartz, C.H., Brabander, D.J., Harvey, C., Hemond, H.F., 2001. Validation of an arsenic sequential extraction method for evaluating mobility in sediments. Environ. Sci. Technol. 35 (13), 2778-2784.

Khan, S., Kazi, T.G., Kolachi, N.F., Afridi, I., Ullah, N., 2013. Sequential extraction of vanadium in different soil samples using conventional and ultrasonic devices. J. AOAC Int. 96 (3), 650-656.

Klein, C., Hurlbut, C.S., Dana, J.D., Mineraloge, G., 1993. Manual of mineralogy. New York, USA, Wiley.

Lazaridis, N., Jekel, M., Zouboulis, A., 2003. Removal of Cr (VI), Mo (VI), and V (V) ions from single metal aqueous solutions by sorption or nanofiltration. Sep. Sci. Technol. 38 (10), 2201-2219.

Lente, G., Magalhães, M.E.A., Fábián, I., 2000. Kinetics and mechanism of complex formation reactions in the iron (III)-phosphate ion system at large iron (III) excess. Formation of a tetranuclear complex. Inorg. Chem. 39 (9), 1950-1954. 
Li, X., Coles, B.J., Ramsey, M.H., Thornton, I., 1995. Sequential extraction of soils for multielement analysis by ICP-AES. Chem. Geol. 124 (1), 109-123.

Lookman, R., Freese, D., Merckx, R., Vlassak, K., van Riemsdijk, W.H., 1995. Long-term kinetics of phosphate release from soil. Environ. Sci. Technol. 29 (6), 1569-1575.

Okoro, H.K., Fatoki, O.S., Adekola, F.A., Ximba, B.J., Snyman, R.G., 2012. A review of sequential extraction procedures for heavy metals speciation in soil and sediments. Open Acc. Sci. Rep. 1, 1-9.

Pueyo, M., Mateu, J., Rigol, A., Vidal, M., López-Sánchez, J.F., Rauret, G., 2008. Use of the modified BCR three-step sequential extraction procedure for the study of trace element dynamics in contaminated soils. Environ. Pollut. 152 (2), 330-341.

Peacock, C.L., Sherman, D.M., 2004. Vanadium (V) adsorption onto goethite $(\alpha-\mathrm{FeOOH})$ at $\mathrm{pH} 1.5$ to 12: a surface complexation model based on ab initio molecular geometries and EXAFS spectroscopy. Geochim. Cosmochim. Acta 68 (8), 1723-1733.

Perles, T., 2012. Vanadium market fundamentals and implications. Metal Bulletin 28th International Ferroalloys Conference. Berlin, Germany.

Prathap, K., Namasivayam, C., 2010. Adsorption of vanadate(V) on $\mathrm{Fe}(\mathrm{III}) / \mathrm{Cr}(\mathrm{III})$ hydroxide waste. Environ. Chem. Lett. 8 (4), 363-371.

Pyrzyńska, K., Wierzbicki, T., 2004. Determination of vanadium species in environmental samples. Talanta 64 (4), 823-829.

Rao, B.R., Bailey, J., Wingwafi, R.W., 2011. Comparison of three digestion methods for total soil potassium estimation in soils of Papua New Guinea derived from varying parent materials. Commun. Soil Sci. Plant Anal. 42 (11), 1259-1265.

Rao, C., Sahuquillo, A., Sanchez, J.L., 2008. A review of the different methods applied in environmental geochemistry for single and sequential extraction of trace elements in soils and related materials. Water, Air, Soil Pollut. 189 (1-4), 291-333.

Reimann, C., Caritat, P.D., 1998. Chemical elements in the environment: Factsheets for the geochemist and environmental scientist. Berlin, Springer.

Rauret, G., López-Sánchez, J.F., Sahuquillo, A., Rubio, R., Davidson, C., Ure, A., Quevauviller, $\mathrm{Ph}$. 1999. Improvement of the BCR three step sequential extraction procedure prior to the certification of new sediment and soil reference materials. J. Environ. Monit. 1, 57-61. 
Rinklebe, J., Shaheen, S.M., 2014. Assessing the mobilization of cadmium, lead, and nickel using a seven-step sequential extraction technique in contaminated floodplain soil profiles along the central Elbe River, Germany. Water, Air, \& Soil Pollut. 225 (8), 1-20.

Rietra, R.P., Hiemstra, T., van Riemsdijk, W.H., 1999. The relationship between molecular structure and ion adsorption on variable charge minerals. Geochim. Cosmochim. Acta 63 (19), 3009-3015.

Rousis, N.I., Pasias, I.N., Thomaidis, N.S., 2014. Attenuation of interference in collision/reaction cell inductively coupled plasma mass spectrometry, using helium and hydrogen as cell gases-application to multi-element analysis of mastic gum. Anal. Method. 6 (15), 5899-5908.

Shaheen, S.M., Rinklebe, J., 2014. Geochemical fractions of chromium, copper, and zinc and their vertical distribution in floodplain soil profiles along the Central Elbe River, Germany. Geoderma 228, 142-159.

Scheinost, A.C., Kretzschmar, R., Pfister, S., Roberts, D.R., 2002. Combining selective sequential extractions, X-ray absorption spectroscopy, and principal component analysis for quantitative zinc speciation in soil. Environ. Sci. Technol. 36 (23), 5021-5028.

Schwertmann, U., Pfab, G., 1994. Structural vanadium in synthetic goethite. Geochim. Cosmochim. Acta 58 (20), 4349-4352.

Shi, H., Witt, E.C., Shu, S., Su, T., Wang, J., Adams, C., 2010. Toxic trace element assessment for soils/sediments deposited during Hurricanes Katrina and Rita from Southern Louisiana, USA: a sequential extraction analysis. Environ. Toxicol. Chem. 29 (7), 1419-1428.

Silveira, M.L., Alleoni, L.R.F., O'connor, G.A., Chang, A.C., 2006. Heavy metal sequential extraction methods-a modification for tropical soils. Chemosphere 64 (11), 1929-1938.

Sparks, D.L., 2003. Environmental soil chemistry, 2nd ed. California, USA, Elsevier Science.

Stalikas, C.D., Pilidis, G.A., Tzouwara-Karayanni, S.M., 1999. Use of a sequential extraction scheme with data normalisation to assess the metal distribution in agricultural soils irrigated by lake water. Sci. Total Environ. 236 (1), 7-18.

Teng, Y., Ni, S., Zhang, C., Wang, J., Lin, X., Huang, Y., 2006. Environmental geochemistry and ecological risk of vanadium pollution in Panzhihua mining and smelting area, Sichuan, China. Chin. J. Geochem. 25, 379-385. 
Teng, Y., Yang, J., Sun, Z., Wang, J., Zuo, R., Zheng, J., 2011a. Environmental vanadium distribution, mobility and bioaccumulation in different land-use Districts in Panzhihua Region, SW China. Environ. Monit. Assess. 176 (1-4), 605-620.

Teng, Y., Yang, J., Wang, J., Song, L., 2011b. Bioavailability of vanadium extracted by EDTA, $\mathrm{HCl}, \mathrm{HOAC}$, and $\mathrm{NaNO}_{3}$ in topsoil in the Panzhihua urban park, located in Southwest China. Biol. Trace Elem. Res. 144 (1-3), 1394-1404.

Terzano, R., Spagnuolo, M., Vekemans, B., De Nolf, W., Janssens, K., Falkenberg, G., et al., 2007. Assessing the origin and fate of $\mathrm{Cr}, \mathrm{Ni}, \mathrm{Cu}, \mathrm{Zn}, \mathrm{Pb}$, and $\mathrm{V}$ in industrial polluted soil by combined microspectroscopic techniques and bulk extraction methods. Environ. Sci. Technol. 41 (19), 6762-6769.

Tessier, A., Campbell, P.G., Bisson, M., 1979. Sequential extraction procedure for the speciation of particulate trace metals. Anal. Chem. 51 (7), 844-851.

Thieme, J., Sedlmair, J., Gleber, S.-C., Prietzel, J., Coates, J., Eusterhues, K., Abbt-Braun, G., Salome, M., 2010. X-ray spectromicroscopy in soil and environmental sciences. J. Synchrotron Rad. 17 (2), 149-157.

Tian, L., Yang, J., Alewell, C., Huang, J.-H., 2014. Speciation of vanadium in Chinese cabbage (Brassica rapa L.) and soils in response to different levels of vanadium in soils and cabbage growth. Chemosphere 111, 89-95.

Unsal, Y.E., Tuzen, M., Soylak, M., 2014. Sequential extraction procedure for the determination of some trace elements in fertilizer samples. J. AOAC Int. 97 (4), 10341038.

Ure, A.M., Quevauviller, P., Muntau, H., Griepink, B., 1993. Speciation of heavy metals in soils and sediments. An account of the improvement and harmonization of extraction techniques undertaken under the auspices of the BCR of the Commission of the European Communities. Int. J. Environ. Anal. Chem. 51 (1-4), 135-151.

Wang, C.-F., Chang, C.Y., Chin, C.J., Men, L.C., 1999. Determination of arsenic and vanadium in airborne related reference materials by inductively coupled plasma-mass spectrometry. Anal. Chim. Acta 392 (2), 299-306.

Wenzel, W.W., Brandstetter, A., Wutte, H., Lombi, E., Prohaska, T., Stingeder, G., et al., 2002. Arsenic in field-collected soil solutions and extracts of contaminated soils and its implication to soil standards. J. Plant Nutr. Soil Sci. 165 (2), 221-228. 
Wenzel, W.W., Kirchbaumer, N., Prohaska, T., Stingeder, G., Lombi, E., Adriano, D.C., 2001. Arsenic fractionation in soils using an improved sequential extraction procedure. Anal. Chim. Acta 436 (2), 309-323.

WHO, 2000. Chapter 6.12: Vanadium, 2nd ed. Copenhagen, Denmark, WHO Regional Office for Europe (WHO Regional Publications, European Series, No. 91).

Yang, J., Tang, Y., Yang, K., Rouff, A.A., Elzinga, E.J., Huang, J.-H., 2014. Leaching characteristics of vanadium in mine tailings and soils near a vanadium titanomagnetite mining site. J. Hazard. Mater. 264, 498-504.

Yang, J., Yang, K., Li, T., Tang, Y., Huang, J.-H., 2010. Determination of total V, V(V) and V(IV) in environmental samples: A review. Ecol. Environ. Sci. 19 (3), 518-527.

Yuan, C.-G., Shi, J.-B., He, B., Liu, J.-F., Liang, L.-N., Jiang, G.-B., 2004. Speciation of heavy metals in marine sediments from the East China Sea by ICP-MS with sequential extraction. Environ. Int. 30 (6), 769-783.

Žemberyová, M., Jankovič, R., Hagarová, I., Kuss, H.-M., 2007. Electrothermal atomic absorption spectrometric determination of vanadium in extracts of soil and sewage sludge certified reference materials after fractionation by means of the Communities Bureau of Reference modified sequential extraction procedure. Spectrochim. Acta B 62 (5), 509-513.

Zimmerman, A.J., Weindorf, D.C., 2010. Heavy metal and trace metal analysis in soil by sequential extraction: a review of procedures. Int. J. Anal. Chem. 2010 (2010). 


\section{Figure legend}

Fig. 1 Relative distribution of V in different fractions of sequential extraction I (SE I) (a) and sequential extraction II (SE II) (b) in the mining and forest soil. The data was the mean values of three replicates extractions.

Fig. 2 Relative distribution of $\mathrm{V}$ in different fractions of the proposed eight-step sequential extraction in the smelter, wetland and paddy soils. The data was the mean values of three replicates extractions. 
JES-15-02237 Figures

Water-soluble

Organic matter

Very poorly crystalline $\mathrm{Fe}$ and $\mathrm{Al}$ (hydr)oxides

Crystalline $\mathrm{Fe}$ and $\mathrm{Al}$ (hydr)oxides

Amorphous $\mathrm{Fe}$ and $\mathrm{Al}$ (hydr)oxides (only in figure b)

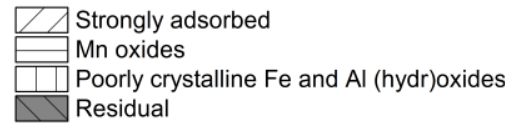

Residual

a: SE I

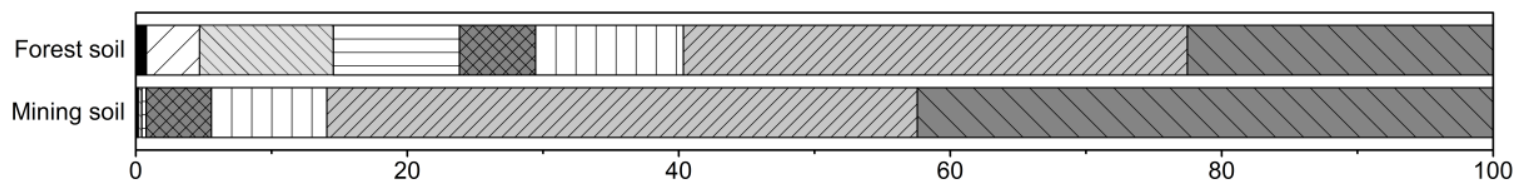

b: SE II

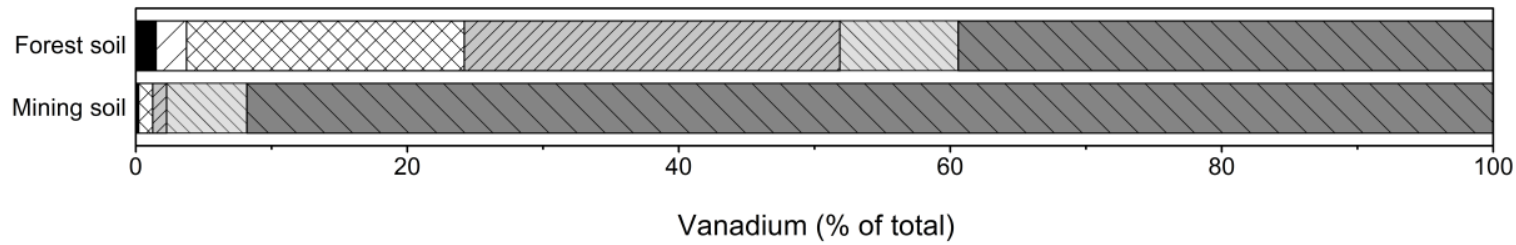

Fig. 1 Relative distribution of V in different fractions of sequential extraction I (SE I) (a) and sequential extraction II (SE II) (b) in the mining and forest soil. The data was the mean values of three replicates extractions.

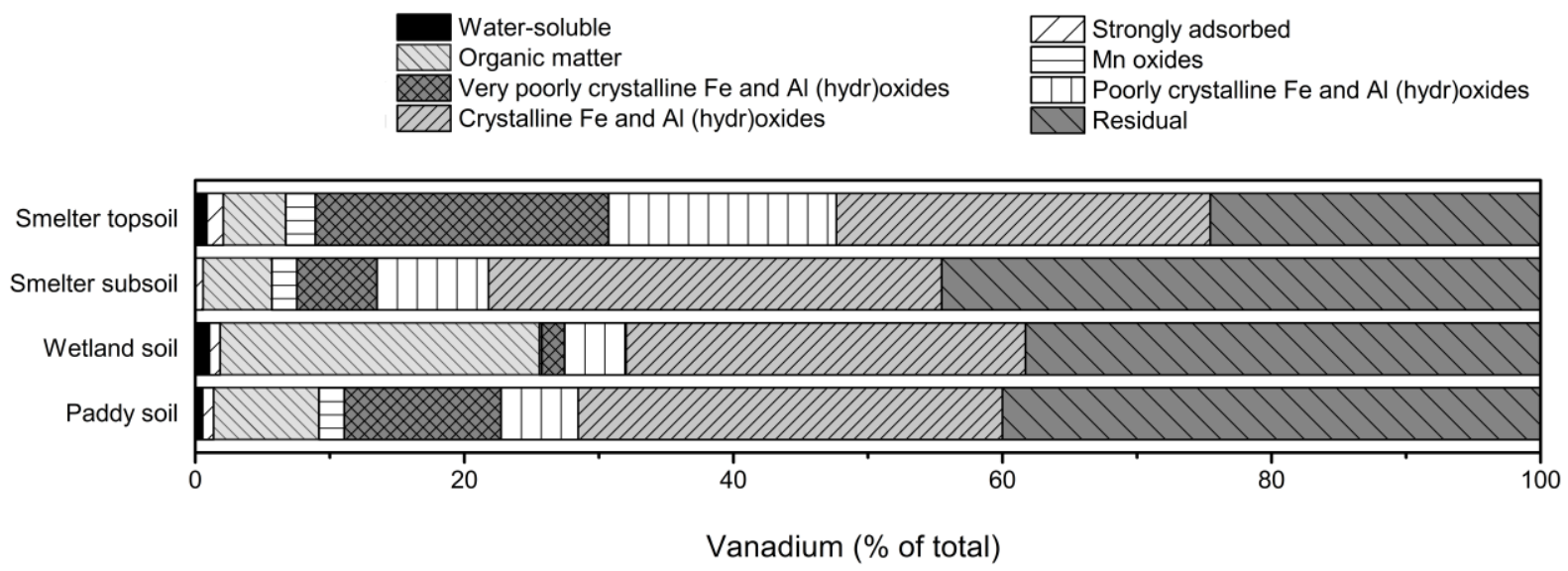

Fig. 2 Relative distribution of $\mathrm{V}$ in different fractions of the proposed eight-step sequential extraction in the smelter, wetland and paddy soils. The data was the mean values of three replicates extractions. 
JES-15-02237 tables

Table 1 Summary of the sequential extraction procedures used for the fractionation of $\mathrm{V}$ in mineral soils in the literature.

\begin{tabular}{|c|c|c|c|}
\hline Soil sample & Target fraction & Extraction solution & $\begin{array}{l}\text { Averaged } \\
\text { percentage of each } \\
\text { fraction }(\%)\end{array}$ \\
\hline \multicolumn{4}{|l|}{ (Modified) BCR } \\
\hline \multirow{4}{*}{$\begin{array}{l}\text { Soils in smelting, mining and agricultural areas } \\
\text { and urban parks in China, } \mathrm{V}_{\text {total }}: 71.7-938 \mathrm{mg} / \mathrm{kg} \\
(n=55) \text { (Teng et al., 2011a). }\end{array}$} & Acid soluble & $0.11 \mathrm{~mol} / \mathrm{L} \mathrm{HOAc}$ & 0.11 \\
\hline & Reducible & $0.5 \mathrm{~mol} / \mathrm{L} \mathrm{NH}_{2} \mathrm{OH} \cdot \mathrm{HCl}$ & 4.96 \\
\hline & Oxidisable & $8.8 \mathrm{~mol} / \mathrm{L} \mathrm{H}_{2} \mathrm{O}_{2}, 1 \mathrm{~mol} / \mathrm{L} \mathrm{NH}_{4} \mathrm{OAc}$ & 9.06 \\
\hline & Residual & $\mathrm{HCl}-\mathrm{HNO}_{3}$ & $84.9^{*}$ \\
\hline \multirow{4}{*}{$\begin{array}{l}\text { Surface soils collected at industrial and } \\
\text { agricultural sites in Pakistan, } V_{\text {total }}: 18-108 \mathrm{mg} / \mathrm{kg} \\
(n=4)(\text { Khan et al., 2013) }\end{array}$} & Exchangeable and Acid soluble & $0.11 \mathrm{~mol} / \mathrm{L} \mathrm{HOAc}$ & 1.90 \\
\hline & Reducible & $0.5 \mathrm{~mol} / \mathrm{L} \mathrm{NH}_{2} \mathrm{OH} \cdot \mathrm{HCl}$ & 12.1 \\
\hline & Oxidisable & $30 \% \mathrm{~mol} / \mathrm{L} \mathrm{H}_{2} \mathrm{O}_{2}, 1 \mathrm{~mol} / \mathrm{L} \mathrm{NH}_{4} \mathrm{OAc}$ & 5.58 \\
\hline & Residual & $\mathrm{HNO}_{3}-\mathrm{HF}-\mathrm{H}_{2} \mathrm{SO}_{4}-\mathrm{H}_{2} \mathrm{O}_{2}$ or $\mathrm{HNO}_{3}-\mathrm{HF}-\mathrm{H}_{2} \mathrm{SO}_{4}-\mathrm{HClO}_{4}$ & 74.5 \\
\hline \multirow{4}{*}{$\begin{array}{l}\text { Industrial soils polluted with } \mathrm{V} \text { in Italy, } \mathrm{V}_{\text {total }} \text { : } \\
1668 \mathrm{mg} / \mathrm{kg} \text { with the predominance of } \mathrm{V}(\mathrm{V}) \\
(n=1)(\text { Terzano et al., } 2007)\end{array}$} & Exchangeable and Acid soluble & $0.11 \mathrm{~mol} / \mathrm{L} \mathrm{HOAc}$ & 1 \\
\hline & Reducible & $0.5 \mathrm{~mol} / \mathrm{L} \mathrm{NH}_{2} \mathrm{OH} \cdot \mathrm{HCl}$ & 40 \\
\hline & Oxidisable & $30 \% \mathrm{H}_{2} \mathrm{O}_{2}$ & 16 \\
\hline & Residual & Aqua regia & 43 \\
\hline \multirow{4}{*}{$\begin{array}{l}\text { Soils collected at an industrial sites in England, } \\
\mathrm{V}_{\text {total }} \text { : } 85-250 \mathrm{mg} / \mathrm{kg}(n=5) \text { (Davidson et al., 1998) }\end{array}$} & Acid soluble/exchangeable & $0.11 \mathrm{~mol} / \mathrm{L} \mathrm{HOAc}$ & 0.98 \\
\hline & Reducible & $0.1 \mathrm{~mol} / \mathrm{L} \mathrm{NH} \mathrm{NH}_{2} \mathrm{OH} \cdot \mathrm{HCl}$ & 12.0 \\
\hline & Oxidisable & $8.8 \mathrm{~mol} / \mathrm{L} \mathrm{H}_{2} \mathrm{O}_{2}, 1 \mathrm{~mol} / \mathrm{L} \mathrm{NH}_{4} \mathrm{OAc}$ & 16.0 \\
\hline & Residual & Aqua regia & 71.0 \\
\hline
\end{tabular}




\begin{tabular}{|c|c|c|c|}
\hline \multirow{4}{*}{$\begin{array}{l}\text { Reference soil materials, } V_{\text {total }}: 87.5-98.3 \mathrm{mg} / \mathrm{kg} \\
(n=3) \text { (Žemberyová et al., 2007) }\end{array}$} & Carbonate, exchangeable & $0.11 \mathrm{~mol} / \mathrm{L} \mathrm{HOAc}$ & 0 \\
\hline & Iron/manganese oxyhydroxides & $0.5 \mathrm{~mol} / \mathrm{L} \mathrm{NH} \mathrm{H}_{2} \mathrm{OH} \cdot \mathrm{HCl}$ & 4.82 \\
\hline & Organic matter and sulphides & $8.8 \mathrm{~mol} / \mathrm{L} \mathrm{H}_{2} \mathrm{O}_{2}, 1 \mathrm{~mol} / \mathrm{L} \mathrm{NH}_{4} \mathrm{OAc}$ & 3.56 \\
\hline & Residual & Aqua regia & 91.6 \\
\hline \multicolumn{4}{|l|}{ (Modified) Tessier et al. (1979) } \\
\hline \multirow{6}{*}{$\begin{array}{l}\text { An agricultural soil in the vicinity of a V-Ti } \\
\text { magnetite mining site in China, } \mathrm{V}_{\text {total }}: 71.8 \mathrm{mg} / \mathrm{kg} \\
(n=1) \text { (Yang et al., 2014) }\end{array}$} & \multirow{6}{*}{$\begin{array}{l}\text { Exchangeable } \\
\text { Carbonates } \\
\text { Fe and Mn oxides } \\
\text { Organic matter } \\
\text { Residual }\end{array}$} & $1 \mathrm{~mol} / \mathrm{L} \quad \mathrm{MgCl}_{2}$ & 0 \\
\hline & & $1 \mathrm{~mol} / \mathrm{L} \quad \mathrm{HOAc} / \mathrm{NaOAc}$ & 0.14 \\
\hline & & $0.04 \mathrm{~mol} / \mathrm{L} \mathrm{NH}{ }_{2} \mathrm{OH} . \mathrm{HCl}$ in $25 \% \mathrm{HOAc}$ & 6.96 \\
\hline & & $0.02 \mathrm{~mol} / \mathrm{L} \mathrm{HNO}_{3}-\mathrm{H}_{2} \mathrm{O}_{2}, 3.2 \mathrm{~mol} / \mathrm{L} \mathrm{NH}_{4} \mathrm{OAc}$ in & 13.2 \\
\hline & & $20 \% \mathrm{HNO}_{3}$ & \\
\hline & & $\mathrm{HCl}-\mathrm{HNO}_{3}$ & 79.7 \\
\hline \multirow{6}{*}{$\begin{array}{l}\text { Soils contaminated with industrial wastes in Italy, } \\
\mathrm{V}_{\text {total }}: 35.5-68.4 \mathrm{mg} / \mathrm{kg}(n=21) \text { (Abollino et al., } \\
\text { 2006) }\end{array}$} & \multirow{6}{*}{$\begin{array}{l}\text { Exchangeable } \\
\text { Carbonates } \\
\text { Fe and Mn oxides } \\
\text { Organic matter } \\
\text { Residual }\end{array}$} & $1 \mathrm{~mol} / \mathrm{L} \quad \mathrm{MgCl}_{2}$ & 0.63 \\
\hline & & $1 \mathrm{~mol} / \mathrm{L}$ HOAc, $\mathrm{NaOAc}$ & 1.25 \\
\hline & & $0.04 \mathrm{~mol} / \mathrm{L} \mathrm{NH} \mathrm{N}_{2} \mathrm{OH} \cdot \mathrm{HCl}$ in $25 \% \mathrm{HOAc}$ & 14.0 \\
\hline & & $0.02 \mathrm{~mol} / \mathrm{L} \mathrm{HNO}_{3}-\mathrm{H}_{2} \mathrm{O}_{2}, 3.2 \mathrm{~mol} / \mathrm{L} \mathrm{NH} \mathrm{NH}_{4} \mathrm{OAc}$ in & 2.48 \\
\hline & & $20 \% \mathrm{HNO}_{3}$ & \\
\hline & & Aqua regia- $\mathrm{HF}, \mathrm{H}_{3} \mathrm{BO}_{3}$ & 79.5 \\
\hline \multirow{7}{*}{$\begin{array}{l}\text { Soils from Spain externally spiked with } \mathrm{V}, \mathrm{V}_{\text {total }} \text { : } \\
472-2274 \mathrm{mg} / \mathrm{kg}(n=5) \quad \text { (Castillo-Carrión et al., } \\
2007)\end{array}$} & \multirow{7}{*}{$\begin{array}{l}\text { Soluble } \\
\text { Exchangeable } \\
\text { Carbonates } \\
\text { Fe and Mn oxides } \\
\text { Organic matter } \\
\text { Residual }\end{array}$} & Distilled water & 0.28 \\
\hline & & $1 \mathrm{~mol} / \mathrm{L} \quad \mathrm{MgCl}_{2}$ & 0.12 \\
\hline & & $1 \mathrm{~mol} / \mathrm{L}$ HOAc, $\mathrm{NaOAc}$ & 1.96 \\
\hline & & $0.04 \mathrm{~mol} / \mathrm{L} \mathrm{NH} \mathrm{H}_{2} \mathrm{OH} \cdot \mathrm{HCl}$ in $25 \% \mathrm{HOAc}$ & 64.0 \\
\hline & & $0.02 \mathrm{~mol} / \mathrm{L} \mathrm{HNO}_{3}-\mathrm{H}_{2} \mathrm{O}_{2}, 3.2 \mathrm{~mol} / \mathrm{L} \mathrm{NH} \mathrm{NH}_{4} \mathrm{OAc}$ in & 7.18 \\
\hline & & $20 \% \mathrm{HNO}_{3}$ & \\
\hline & & $\mathrm{HF} \mathrm{HClO}_{4}$ mixture & 26.6 \\
\hline
\end{tabular}




\begin{tabular}{|c|c|c|c|}
\hline $\begin{array}{l}\text { Soils and sediments influenced by hurricane } \\
\text { Katrina in USA, } \mathrm{V}_{\text {total }} \text { : } 18.4-126 \mathrm{mg} / \mathrm{kg} \quad(n=51) \\
\text { (Shi et al., 2010) }\end{array}$ & $\begin{array}{l}\text { Exchangeable } \\
\text { Carbonates } \\
\text { Fe and Mn oxides } \\
\text { Organic matter } \\
\text { Residual }\end{array}$ & 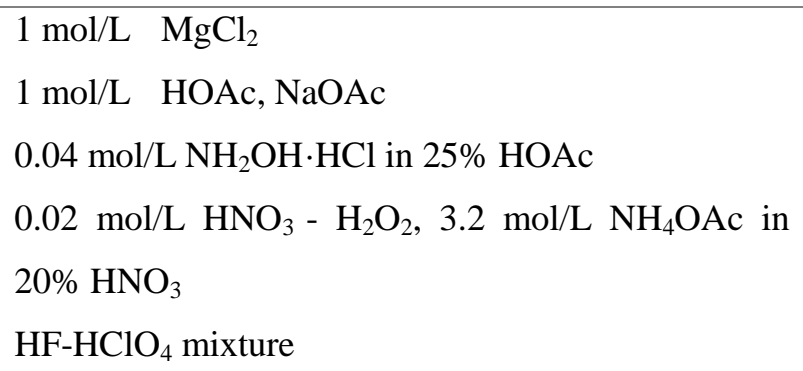 & $\begin{array}{l}0 \\
0 \\
18.0 \\
8.12\end{array}$ \\
\hline $\begin{array}{l}\text { Soil reference materials, } \mathrm{V}_{\text {total }}: 28.4-109 \mathrm{mg} / \mathrm{kg} \\
(n=7)(\mathrm{Li} \text { et al., } 1995)\end{array}$ & $\begin{array}{l}\text { Exchangeable } \\
\text { Carbonates and specifically adsorbed } \\
\text { Fe and Mn oxides } \\
\text { Organic matter } \\
\text { Residual }\end{array}$ & $\begin{array}{l}0.5 \mathrm{~mol} / \mathrm{L} \quad \mathrm{MgCl}_{2} \\
1 \mathrm{~mol} / \mathrm{L} \mathrm{HOAc}, \mathrm{NaOAc} \\
0.04 \mathrm{~mol} / \mathrm{L} \mathrm{NH} \mathrm{OH}_{2} \mathrm{HCl} \text { in } 25 \% \mathrm{HOAc} \\
0.02 \mathrm{~mol} / \mathrm{L} \mathrm{HNO}_{3}-\mathrm{H}_{2} \mathrm{O}_{2}, 3.2 \mathrm{~mol} / \mathrm{L} \mathrm{NH} \mathrm{NH}_{4} \mathrm{OAc} \text { in } \\
20 \% \mathrm{HNO}_{3} \\
\mathrm{HNO}_{3}-\mathrm{HF}^{-} \mathrm{HClO}_{4}\end{array}$ & $\begin{array}{l}0.19 \\
0.91 \\
11.3 \\
6.85\end{array}$ \\
\hline $\begin{array}{l}\text { Industrial and agricultural soils in Turkey, } \mathrm{V}_{\text {total }} \text { : } \\
17.9-36.6 \mathrm{mg} / \mathrm{kg}(n=30) \text { (Güler et al., 2010) }\end{array}$ & $\begin{array}{l}\text { Exchangeable } \\
\text { Carbonates } \\
\text { Fe and Mn oxides } \\
\text { Organic matter } \\
\text { Residual }\end{array}$ & $\begin{array}{l}0.5 \mathrm{~mol} / \mathrm{L} \quad \mathrm{MgCl}_{2} \\
1 \mathrm{~mol} / \mathrm{L} \quad \mathrm{HOAc}, \mathrm{NaOAc} \\
0.1 \mathrm{~mol} / \mathrm{L} \mathrm{NH} \mathrm{H}_{2} \mathrm{OH} \cdot \mathrm{HCl} \text { in } \mathrm{HOAc} \\
0.02 \mathrm{~mol} / \mathrm{L} \mathrm{HNO} \mathrm{HNO}_{3}-15 \% \mathrm{H}_{2} \mathrm{O}_{2} \\
\text { Aqua Regia }\end{array}$ & $\begin{array}{l}1.11 \\
2.22 \\
22.4 \\
22.4 \\
\mathbf{5 1 . 8}\end{array}$ \\
\hline $\begin{array}{l}\text { Soils in Poland, } \mathrm{V}_{\text {total }}: 5.58-10.9 \mathrm{mg} / \mathrm{kg} \quad(n=7) \\
\text { (Agnieszka and Barbara, 2012) }\end{array}$ & $\begin{array}{l}\text { Exchangeable } \\
\text { Carbonates } \\
\text { Fe and Mn oxides } \\
\text { Organic matter } \\
\text { Residual }\end{array}$ & 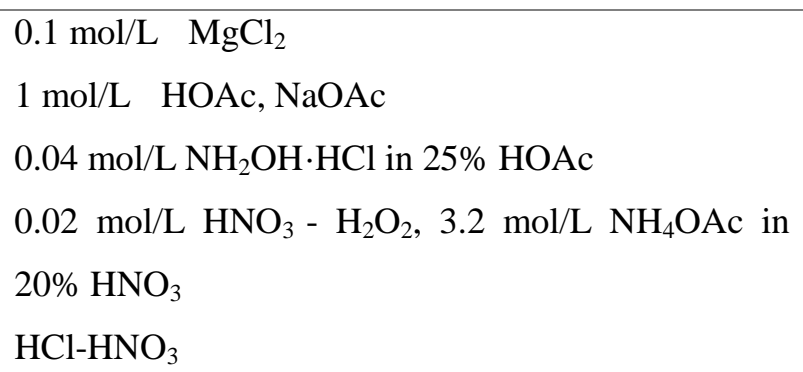 & $\begin{array}{l}1.76 \\
1.97 \\
38.4 \\
18.3\end{array}$ \\
\hline
\end{tabular}




\begin{tabular}{|c|c|c|c|}
\hline \multirow{5}{*}{$\begin{array}{l}\text { An agricultural soil in the vicinity of a V-Ti } \\
\text { magnetite mining site in China, } \mathrm{V}_{\text {total }}: 71.8 \mathrm{mg} / \mathrm{kg} \\
(n=1) \quad \text { (Yang et al., } 2014)\end{array}$} & Non-specifically sorbed & $0.05 \mathrm{~mol} / \mathrm{L}\left(\mathrm{NH}_{4}\right)_{2} \mathrm{SO}_{4}$ & 0.51 \\
\hline & Specifically sorbed & $0.05 \mathrm{~mol} / \mathrm{L} \mathrm{NH}_{4} \mathrm{H}_{2} \mathrm{PO}_{4}$ & 0.30 \\
\hline & Amorphous hydrous $\mathrm{Fe}$ and $\mathrm{Al}$ oxides & $0.2 \mathrm{~mol} / \mathrm{L} \mathrm{NH}_{4}{ }^{+}$-oxalate buffer & 5.52 \\
\hline & Crystalline hydrous $\mathrm{Fe}$ and $\mathrm{Al}$ oxides & $0.2 \mathrm{~mol} / \mathrm{L} \mathrm{NH}_{4}{ }^{+}$-oxalate buffer + ascorbic acid & 9.83 \\
\hline & Residual & $\mathrm{HCl}-\mathrm{HNO}_{3}$ & 83.8 \\
\hline \multirow[t]{5}{*}{$\begin{array}{l}\text { Soil reference materials } \mathrm{V}_{\text {total }}: 36-140 \mathrm{mg} / \mathrm{kg} \\
(n=7)(\text { Hall et al., 1996) }\end{array}$} & $\begin{array}{l}\text { Adsorbed, exchangeable and } \\
\text { carbonate }\end{array}$ & $1 \mathrm{~mol} / \mathrm{L} \mathrm{NaOAc}$ & 0 \\
\hline & Amorphous iron oxyhydroxide & $0.25 \mathrm{~mol} / \mathrm{L} \mathrm{NH} \mathrm{N}_{2} \mathrm{OH} \cdot \mathrm{HCl}$ in $0.05 \mathrm{~mol} / \mathrm{L} \mathrm{HCl}$ & 14.8 \\
\hline & Crystalline iron oxides & $1 \mathrm{~mol} / \mathrm{L} \mathrm{NH} \mathrm{NH}_{2} \mathrm{OH} \cdot \mathrm{HCl}$ in $25 \% \mathrm{HOAc}$ & 24.7 \\
\hline & Organics and sulphides & $\mathrm{KClO}_{3}-\mathrm{HCl}, \mathrm{HNO}_{3}$ & 8.46 \\
\hline & Residual & $\mathrm{HF}-\mathrm{HClO}_{4}-\mathrm{HNO}_{3}$ & 52.9 \\
\hline \multirow{6}{*}{$\begin{array}{l}\text { Soils irrigated with waste water in Ethiopia, } \mathrm{V}_{\text {total }} \text { : } \\
9.22-87.4 \mathrm{mg} / \mathrm{kg}(n=4) \text { (Fitamo et al., 2007) }\end{array}$} & & $1 \mathrm{~mol} / \mathrm{L} \mathrm{NH}_{4} \mathrm{NO}_{3}$ & 0.07 \\
\hline & & $0.5 \mathrm{~mol} / \mathrm{L} \mathrm{NH}_{4} \mathrm{OAc}, 0.02 \mathrm{~mol} / \mathrm{L} \mathrm{EDTA}$ & 14.4 \\
\hline & \multirow{2}{*}{ Reducible } & $0.175 \mathrm{~mol} / \mathrm{L} \mathrm{NH}_{4}^{+}$-oxalate buffer $/ 0.1 \mathrm{~mol} / \mathrm{L}$ oxalic & 44.8 \\
\hline & & acid & \\
\hline & \multirow{2}{*}{ Residual } & $0.1 \mathrm{~mol} / \mathrm{L} \mathrm{Na}_{4} \mathrm{P}_{2} \mathrm{O}_{7}$ & Not determined \\
\hline & & $7 \mathrm{~mol} / \mathrm{L} \mathrm{HNO}_{3}$ & 40.5 \\
\hline
\end{tabular}

$n$ : number of soils investigated.

* Bold highlights the prevalent fraction. 
Table 2 Characterisations of the soils used in this study.

\begin{tabular}{lllllll}
\hline Parameter & $\begin{array}{l}\text { Mining } \\
\text { soil }\end{array}$ & $\begin{array}{l}\text { Forest } \\
\text { soil }\end{array}$ & $\begin{array}{l}\text { Smelter } \\
\text { topsoil }\end{array}$ & $\begin{array}{l}\text { Smelter } \\
\text { subsoil }\end{array}$ & $\begin{array}{l}\text { Wetland } \\
\text { soil }\end{array}$ & $\begin{array}{l}\text { Paddy } \\
\text { soil }\end{array}$ \\
\hline $\mathrm{pH}$ & 7.60 & 3.49 & 8.00 & 8.32 & 4.70 & 6.95 \\
Organic C & 2.15 & 8.27 & 10.9 & 2.58 & 5.56 & 2.90 \\
$(\%)$ & & & & & \\
$\mathrm{V}(\mathrm{mg} / \mathrm{kg})$ & 343 & 48.8 & 784 & 150 & 23.5 & 111 \\
$\mathrm{Fe}(\%)$ & 11.1 & 1.69 & 24.0 & 5.04 & 1.09 & 4.31 \\
$\mathrm{Mn}(\%)$ & 0.15 & 0.01 & 0.23 & 0.66 & 0.02 & 0.05 \\
$\mathrm{Al}(\%)$ & 3.14 & 5.15 & 2.73 & 4.31 & 5.66 & 6.42 \\
$\mathrm{Si}(\%)$ & 10.0 & 23.6 & 8.56 & 13.1 & 22.4 & 23.2 \\
\hline
\end{tabular}

Table 3 Sequential Extraction procedures for $\mathrm{V}$ fractionation in mineral soils proposed in this study.

\begin{tabular}{lll}
\hline Target fraction & Operation condition & Extraction condition \\
SE I &
\end{tabular}

1 Water-soluble $15 \mathrm{~mL}$ de-ionised water $\quad$ RT, $6 \mathrm{hr}$

2 Strongly adsorbed $25 \mathrm{~mL}$ of $5 \mathrm{mmol} / \mathrm{L}$ phosphate $\mathrm{RT}, 8 \mathrm{hr}$ $\left(\mathrm{NH}_{4} \mathrm{H}_{2} \mathrm{PO}_{4}\right), \mathrm{pH} 4.5$

3 Organic matter $\quad 25 \mathrm{~mL}$ of $0.1 \quad \mathrm{~mol} / \mathrm{L} \quad \mathrm{RT}, 4 \mathrm{hr}$

pyrophosphate

$\left(\mathrm{Na}_{4} \mathrm{P}_{2} \mathrm{O}_{7} \cdot 10 \mathrm{H}_{2} \mathrm{O}\right)$

4 Mn oxides $25 \mathrm{~mL}$ of $0.4 \mathrm{~mol} / \mathrm{L} \mathrm{NH}_{2} \mathrm{OH} \cdot \mathrm{HCl}, \mathrm{RT}, 2 \mathrm{hr}$

pH 3.2

5 Very poorly crystalline $25 \mathrm{~mL}$ of $1 \mathrm{~mol} / \mathrm{L} \mathrm{HCl} \quad \mathrm{RT}, 4 \mathrm{hr}, 1$ repetition Fe and $\mathrm{Al}$ (hydr)oxides

6 Poorly crystalline $\mathrm{Fe} 25 \mathrm{~mL}$ of $0.2 \mathrm{~mol} / \mathrm{L} \mathrm{NH}_{4}$-oxalate $\mathrm{RT}, 4 \mathrm{hr}$ in the dark, 1 repetition and $\mathrm{Al}$ (hydr)oxides $\quad$ buffer $(\mathrm{pH} 3.25)$

7 Crystalline $\mathrm{Fe}$ and $\mathrm{Al} 25 \mathrm{~mL}$ of $4 \mathrm{~mol} / \mathrm{L} \mathrm{HCl} \quad 95^{\circ} \mathrm{C}, 3 \mathrm{hr}$, agitation twice per $\mathrm{hr}$ (hydr)oxides

8 Residual $10 \mathrm{~mL}$ of $\mathrm{HNO}_{3}-\mathrm{H}_{2} \mathrm{O}_{2}-\mathrm{HF}$ (5:3:2, Microwave digest: $150^{\circ} \mathrm{C}, 10$ $V / V / V)$ $\min , 190^{\circ} \mathrm{C}, 20 \mathrm{~min}, 100^{\circ} \mathrm{C} 20$ $\min$ 
SE II

1 Water-soluble $\quad 15 \mathrm{~mL}$ de-ionised water $\quad$ RT, $6 \mathrm{hr}$

2 Exchangeable $\quad 25 \mathrm{~mL}$ of $1 \mathrm{~mol} / \mathrm{L} \mathrm{HOAc} \quad \mathrm{RT}, 8 \mathrm{hr}$

3 Amorphous Fe and $\mathrm{Al} 25 \mathrm{~mL}$ of $0.2 \mathrm{~mol} / \mathrm{L} \mathrm{NH}_{4}$-oxalate $20{ }^{\circ} \mathrm{C}, 4 \mathrm{hr}$, in the dark, (hydr)oxides buffer, $\mathrm{pH} 3.25$

4 Crystalline $\mathrm{Fe}$ and $\mathrm{Al} 25 \mathrm{~mL}$ of $0.2 \mathrm{~mol} / \mathrm{L} \mathrm{NH}_{4}$-oxalate $(96 \pm 3)^{\circ} \mathrm{C}, 30 \mathrm{~min}$, occasional (hydr)oxides $\quad$ buffer $+0.1 \mathrm{~mol} / \mathrm{L}$ ascorbic acid, agitation pH 3.25

5 Organic matter $\quad 0.02 \mathrm{~mol} / \mathrm{L} \mathrm{HNO}_{3}+30 \% \mathrm{H}_{2} \mathrm{O}_{2}(85 \pm 2)^{\circ} \mathrm{C}, 4 \mathrm{hr}$, occasional $(W / W), 3.2 \mathrm{~mol} / \mathrm{L} \mathrm{NH}_{4} \mathrm{OAc}$ in agitation $20 \%(V / V) \mathrm{HNO}_{3}$

6 Residual $10 \mathrm{~mL} \mathrm{HNO}_{3}-\mathrm{H}_{2} \mathrm{O}_{2}-\mathrm{HF}$ (5:3:2, Microwave digest: $150^{\circ} \mathrm{C}, 10$ $V / V / V) \quad \min , 190^{\circ} \mathrm{C}, 20 \mathrm{~min}, 100^{\circ} \mathrm{C} 20$ $\min$

RT: room temperature, $(25 \pm 2)^{\circ} \mathrm{C}$. 
Table 4 Dissolution efficiencies of extraction procedures proposed in this study toward Fe and Al minerals of different crystallinity.

\begin{tabular}{|c|c|c|c|c|c|c|}
\hline \multirow{3}{*}{ Extractant $^{\mathrm{a}}$} & Ferrihydrite & Goethite & Boehmite & $\mathrm{Al}(\mathrm{OH})_{3}$ & $\mathrm{MnO}_{2}$ & $\mathrm{FeS}$ \\
\hline & Pooly crystalline & Well-crystalline & Pooly crystalline & Well-crystalline & Well-crystalline & Well-crystalline \\
\hline & \multicolumn{6}{|c|}{ Dissolution efficiency (\%) } \\
\hline Phosphate $(5 \mathrm{mmol} / \mathrm{L})$ & 0 & 0 & 0 & 0 & 0 & 0 \\
\hline Pyrophosphate (0.1 mol/L) & $0.05 \pm 0.01^{\mathrm{b}}$ & $0.54 \pm 0.04$ & $1.27 \pm 0.09$ & $0.29 \pm 0.01$ & $0.03 \pm 0.01$ & $1.16 \pm 0.01$ \\
\hline $\mathrm{NH}_{2} \mathrm{OH} \cdot \mathrm{HCl}(0.4 \mathrm{~mol} / \mathrm{L})$ & $0.11 \pm 0.01$ & $0.09 \pm 0.01$ & $0.95 \pm 0.24$ & $0.07 \pm 0.01$ & $99.7 \pm 2.96$ & $1.27 \pm 0.04$ \\
\hline $\mathrm{HCl}(1 \mathrm{~mol} / \mathrm{L})$ & $95.6 \pm 4.21$ & $3.94 \pm 0.10$ & $6.31 \pm 0.43$ & $1.18 \pm 0.02$ & $0.10 \pm 0.01$ & $17.5 \pm 0.17$ \\
\hline Oxalate buffer $(0.2 \mathrm{~mol} / \mathrm{L})$ & $71.5 \pm 3.15$ & $4.61 \pm 0.07$ & $10.9 \pm 0.90$ & $0.40 \pm 0.01$ & $37.2 \pm 1.13$ & $6.06 \pm 0.91$ \\
\hline $\mathrm{HCl}\left(4 \mathrm{~mol} / \mathrm{L}, 95^{\circ} \mathrm{C}\right)$ & $98.7 \pm 1.88$ & $98.9 \pm 1.62$ & $95.4 \pm 1.90$ & $100 \pm 1.49$ & $52.1 \pm 0.42$ & $64.1 \pm 0.95$ \\
\hline
\end{tabular}

${ }^{\text {a }}$ Detailed dissolution conditions are shown in Table 3.

${ }^{\mathrm{b}}$ mean $\pm \mathrm{SD}$. 
